Quartet and John Coltrane's record The Gentle Side of Coltrane: the marvellous freshness of Coltrane's After the Rain was particularly attractive. Both were among the finalists, along with Keith Jarrett's Koln Concert-four prolomged, ecstatic, lyrical piano improvisations. We had seen Jarrett play at the Royal Festival Hall, and he seemed himself to be going into labour at times as he played. Whether his antics and his music are bogus or sincere I've still not decided, but we do enjoy his music. We often eat to it, and music for eating and labouring can't be that different.

The other jazz that Lin considered was all vocal: Ella Fitzgerald singing Gershwin; Astrud Gilberto singing with Stan Get\%, "It might as well be spring"; and Nat King Cole singing with George Shearing. While thinking about songs we also considered Canteloube's Songs of the Auvergne and Berlioz's Les Nuits d'Été, but we eventually decided that words got in the way. For the same reason and because of their exuberance we rejected two of Lin's favourite records, songs from Guys and Dolls and Cabaret: imagine experiencing that divine moment when a new life begins to the strains of "Sit Down, You're Rocking the Boat." It couldn't be.

This process of exclusion took us months, and we were becoming heartily sick of it: silence, or the ticking of all those machines, didn't seem such dreadful options. At least then you wouldn't have to change the tape. God, or whatever it is that starts labour, must have thought so too because labour started before we had made our final decision. We rattled off in the ambulance musicless, and all that St Thomas's could offer was Cliff Richard at the wrong speed. Freddie P Smith's arrival was celebrated only with shrieks, pants, and grunts; and none of us missed the music.

\title{
In praise of the Basuto pony
}

\author{
SAM RAMSAY SMITH
}

It gets cold up in the mountains of Lesotho in winter and yesterday, although it is spring, was no exception. Even though the early morning sun was shining, it was still very cold, but it did not seem to bother me for I was about to embark on an African adventure and was full of anticipation and a certain degree of excitement. I was to go to a village so remote and small that I could barely find it on the large scale map I had of the district-all I knew was that to get there meant a good half a day's ride on horseback over some difficult mountain terrain.

I had been asked as district medical officer to accompany some of the local police to the village of Qabane (no $U$, and pronounced Khabané) some way beyond the north bank of the Orange River and to the north of a town called Sekakes, where we had one of our peripheral health centres. Apparently, I was required to perform an exhumation on a member of the chief's family who had died in March this year and was now known to have been murdered.

\section{A bag of biltong}

At this time of year both my wife Marta and I are extremely busy-much more so than usual since we are finalising the arrangements for transferring our patients from the old hospital to the new one, recently completed and now my responsibility to start running and then to manage for a further two years. Thus we received the request from Lieutenant Colonel Chaka of the Lesotho Mounted Police with mixed feelings; nevertheless, it was in response to this request that I found myself on this cold morning filling my saddle bags at 630 am with a varied assortment of articles from a mortuary kit to a bag of biltong-the dried, preserved meat of various animals from domestic beef to wild antelope, but it is also made from ostrich flesh. I have recently begun to make my own, because of its high price in the shops, and this was an excellent opportunity to try out my first, home made batch, since biltong is extremely nutritious, light to carry, and well preserved, and is the ideal food for this sort of trip.

Just after 700 am I am on my way to Sekakes, the village where I shall leave my Toyota Landcruiser and take to horseback. The early morning sun is magnificent, and the peach blossom is ubiquitous-pink islands on the barren rocks of the mountains competing with the mimosa for a share of the bright colour on the hill sides. Smoke is curling in the early morning light from the roofs of many of the village huts that I pass-trees are scarce in Lesotho, and the primary source of fuel is compressed cow and goat dung-but it is like peat in quality and burns well for a long time if well made. There is little traffic on these twisted mountain roads at the best of times, and I do not pass a single vehicle on my way to Sekakes, a drive of just over 90 minutes.

\section{Black Beauty}

By 900 am I am mounted on a fine, black horse supplied by the police. I am sitting on the saddle I gave Marta as a birthday present-supposed to be very comfortable. I sling my saddle bags over the back of the saddle and we are off; my escort comprises a sergeant of the criminal investigation department and a detective trooper, both heavily armed. They tell me that things can be "awkward" in the mountains, which is why they go armed on these trips and, furthermore, most of the time they went "footing it" since it seems that the mountain people can recognise a police horse from afar and can thus take evasive action at an early stage if deemed necessary.

It takes us an hour to make the long descent to the place where we shall cross the Orange River, but passing down the narrow, winding bridle path we meet many people. There are small groups of men on their ponies, women carrying all manner of goods on their heads, from their own shoes as they cross the river to such interesting items as two chickens, a six can pack of beer, to a door complete in its frame, and then the mules-long lines of them winding slowly up the tortuous track carrying great sacks of maize and barrels of joala, the locally produced foment from maize.

I have travelled to my work in Africa by a variety of meanscanoes in Cameroun, aeroplanes in Zaire, and the footplate of a steam train in Kenya-but the mode of transport I was forced to adopt today is possibly the most pleasant of all. I have never spent more than two hours on horseback continuously before, 
but this morning I spent four and a half hours riding to the village of Qabane where the exhumation was to take place, and I found that there was ample time on horseback at a steady walk to take a good interest in the wide variety of things new to me on this trip. The sergeant and the trooper were fine company and told me many things of interest as we passed along the way.

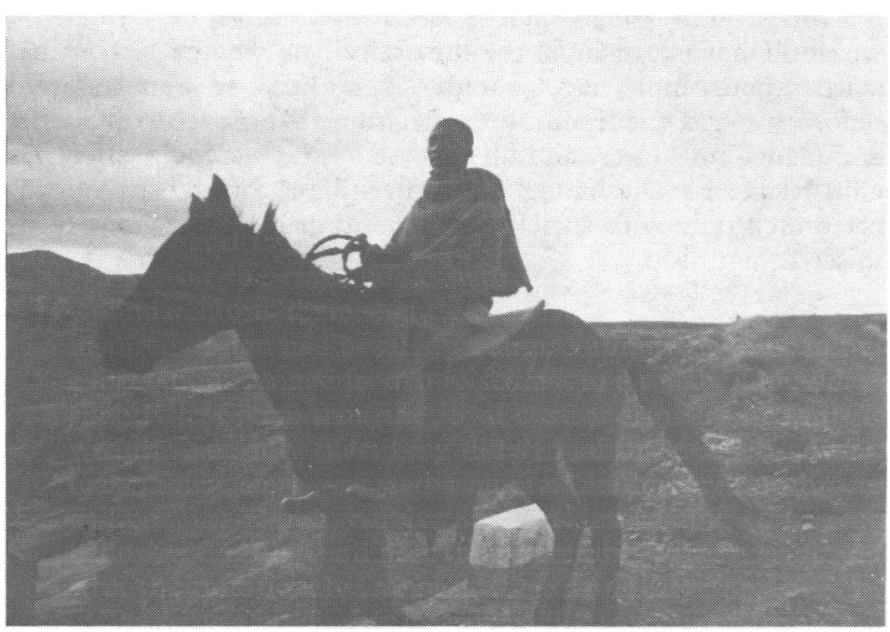

At every bend in the twisting track there was something new to see and reflect on; I remember catching sight of a strange bird that closely resembled an ibis, but with the reddest of red beaks and similarly coloured legs such as I had not seen in other parts of Africa. I have discovered from my books at Qacha's Nek that this was probably an ibis but the "Hadadah" ibis so called because of its loud cry "Ha Da Dah." It is rare that we travel here without seeing something of interest.

\section{Pitso at Qabane}

When we finally arrived at the village of Qabane at $1 \mathrm{pm}$ it was obvious that something special was going on, for I could see over 200 Basuto men plus their horses gathered in the centre of the village. Each man was covered in a large, brightly coloured blanket-the colourful, traditional garb of the Basutos. The sight made a marvellous spectacle against the gaunt backdrop of the huge mass of Mt Qabane $(2500 \mathrm{~m})$. The senior chief was telling the amassed people what was about to happen, speaking in Sesotho, the language of the Basuto. It is a hard language to grasp well, derived as it is from the Bushman dialects of the desert wastes of Southern Africa, full of clicks and grunts. Neither Marta nor I had yet had any free time in which to study it, despite our wish to do so, and so I sat there by the side of my horse, uncomprehending, but glad of the rest it afforded me and those parts I had long forgotten until this ride. I was rather upset to learn from the good sergeant that as soon as the pitso (meeting) had been dissolved everyone was to walk to the top of a mountain whose peak I could see only dimly in the distance whence there flowed a small stream which marked the site of the victim's grave. It looked miles away, and I could hardly bear the thought of a further hour's exercise, being suffused with sartorial and gluteal aches and pains as a result of the ride to the village.

Nevertheless, the pitso closed at $130 \mathrm{pm}$, and I was enjoined to mount by the hordes of Basuto men as they emerged from the meeting. Together we proceeded to climb the mountain in a truly biblical cacophony of colour and shouts. About half way up the mountain the terrain became increasingly steep and eventually, to my dismay, everyone began to dismount and walk to the site of the grave. At this stage in the saga the only thought that kept me going was that unless the reluctant grave diggers were incredibly lucky they were unlikely to strike the body in less than 15 minutes, and to my relief I was proved correct.

\section{Discovery of the body}

In less than half an hour I was standing at the grave site-a small cave that had been crudely blocked off with large boulders. One of the villagers began to dig, heaving earth and stones aside as he searched for traces of the body while I sat on a large stone in the sun drinking coffee and giving thanks for the rest. Suddenly I heard a huge, audible sigh coming from the mountainside and on turning was amazed to see that the whole side of this mountain was covered by the Basuto villagers, their blankets hard against their faces as they tried to keep out the cold wind which had sprung up: there were countless scores of them, all wrapped in vivid blankets, silent, waiting for news of a body - the brother of their chief who was now supposed to have been murdered by revengeful villagers for his part in the murder of his brother's daughter. The sigh was in response to the sight of a partially bleached skull being raised by the grave digger. This was where I was supposed to make my entrée, and I suddenly realised that I was in a unique position, being privy to this remarkable spectacle thousands of miles away from the tiled, Victorian mortuary at the back of the Liverpool Royal Infirmary where I had first been introduced to the delights of postmortem examination.

The skull was intact and showed no signs of external violence: it was shortly followed by the appearance of the mandible and then both lower legs and half of one foot. What had so far been found was badly decomposed but was obviously human-but what of the rest of the body? Despite further excavation no more bones were found, and having explained to the CID sergeant about the missing parts of the body he retired with the suspect for some further interrogation-again, without result. Having assembled all the bones and catalogued them, we were then faced with a further problem-how to transport them to Qacha's Nek, there being no sack available in which to store them. With true inspiration the sergeant solved this in a trice by inviting the detective trooper to remove his overalls and then

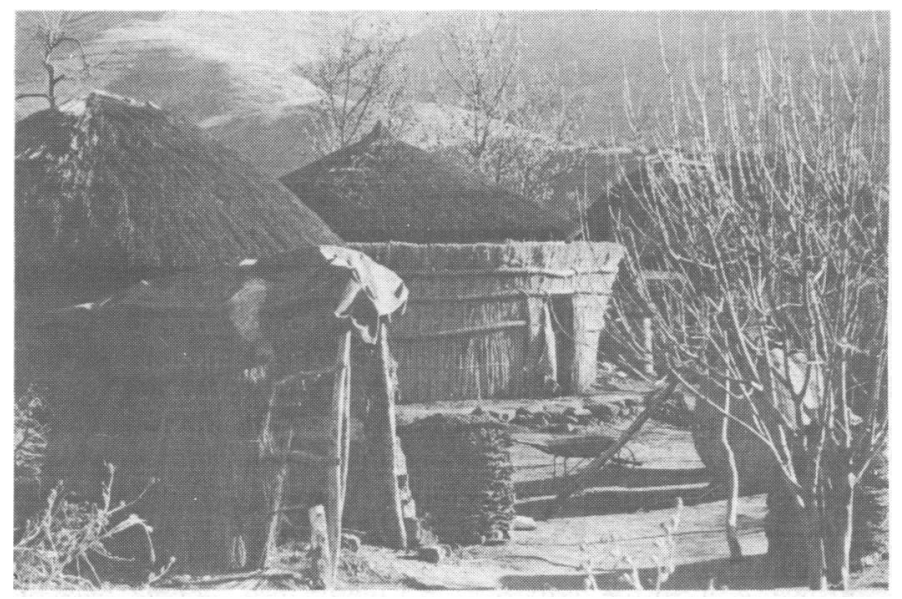

knotting both legs and filling the resulting "sack" with the bones. I never cease to be amazed at the ingenuity of the people we live and work with-though no doubt the trooper was thinking other thoughts.

Before the remains were placed in the sack the chief rose and addressed his people. The sergeant told me he was inviting the people to come and view the remains of their clansman, and so it was that more than 200 curious men came to gaze in wonder at these remains, exclaiming loudly when they saw the skull, for they could not believe how it could be so large. The sergeant told me that none of these people had seen a bare skull beforewhich on reflection is not at all unusual. Then in a huge convoy we all moved slowly back down the mountain to the village. 
By now it was almost $4 \mathrm{pm}$ and I was still optimistic that I could return to Sekakes by 9 pm and thus be back at Qacha's Nek in time to start work the next day if I left at once. After a further, short meeting in the village everyone dispersed in a mass of dust and flying hoofs. I was to return with the trooper and the prisoner while the sergeant made his own way back with the bones.

I bid a friendly farewell to the chief and his family-all of whom were really fine and courteous people-and I was told that I would be welcome at Qabane any time in the future, an offer that Marta and I will try to take up since it is indeed a beautiful place. We had not travelled more than a few kilometres when the sky began to darken and I noticed to the east a huge double rainbow in the sky and following us an even larger cloud of rain. As dusk fell the rain started, slowly at first and then a steady downpour and by $530 \mathrm{pm}$ we were alone in the dark with only the hissing rain and the clip clop of the horses' hoofs for company. At this point the trooper told me that he would be making a small diversion with the prisoner to retrieve a blanket he had left in a nearby village, but I was not to worry since he would soon rejoin me on the bridle path. To this day I have never set eyes on him again.

\section{St Christopher's African cousin}

With no other options open to me I carried on along the twisting track, to my left a precipitous drop of some $60 \mathrm{~m}$ to the gorge of the Orange River, and to my right a barren cliff face. The time passed, pleasantly at first, since there were still the occasional shadowy outlines of villages and the smell of burning dung from the cooking fires of the houses I passed. Just before the light failed completely I spied a lone figure on a horse in the distance, and I hurried to catch up with him. He was an old man, heavily cloaked against the rain, and he gave me to understand that he was also going to Sekakes. We had no language in common but I was glad of his company, for by now darkness had fallen, broken only by frequent bursts of dazzling lightning, and I had absolutely no idea of where I was or should be heading. I knew that we had at least a further two hours of travelling before we would arrive at Sekakes and by now I was beginning to appreciate the daily hardships of the local people as I sat on my good horse, seeing nothing and only trusting blindly that the horse knew the way better than I did.

By $630 \mathrm{pm}$ we were in the epicentre of a violent storm with huge flashes of lightning and deafening bursts of thunder. The bridle path had not been easy during daylight but now it became something of a nightmare as both horses occasionally slipped on the greasy track and I felt helpless since there was no way of guiding the horse. From time to time my old companion drew ahead on his horse and in the total blackness he became invisible: then I would shout out loudly, frightened that he would disappear for good, but each time he would slow down so I could catch up. The rain fell continuously, and I began to feel cold despite wearing two jerseys and a woollen shirt as the rain soaked through my handwoven, woollen poncho that a friend had made in Kenya.

I do not remember a time when I had been so scared for so long, but there seemed little else to do other than to stay on the horse and try not to dwell on the various possibilities if the horse slipped over the edge of the gorge.

After some time I felt the slow descent that led to the banks of the Orange River, and after many a slip and stumble on the greasy path I heard the sound of rushing water. What relief I felt. As my silent companion and I began our crossing I became aware that I could feel water flowing over my boots and using my small pocket torch I saw the river level had risen dramatically since our passage earlier in the day. Each year many people and animals are drowned in the rivers of Lesotho as the heavy rains of spring and summer cause flash flocds that sweep all before them. I could not even see the far bank and had no way of knowing what lay ahead, but my brave horse was nose to tail with my companion so I sat tight and tried to think of sunny days and blue skies and made promises I hoped I would never have to keep, thankfully interrupted by our safe arrival on the southern bank. I was exhilarated to know that the worst was now over and Sekakes lay less than an hour away.

I was by now both cold and tired, and only the reassuring presence of my kind companion kept me going. Who was he, I wondered, and where was he coming from? I shall never know for he left me outside the door of the police station at Sekakes and gently faded into the night, but I like to think that he was St Christopher's African cousin.

\section{Whims of the elements}

I entered the station and sank down gratefully beside the glowing coal stove, not quite believing my luck at having arrived in safety after such an extraordinary day. My jeans were soaked but surprisingly my poncho, although also very wet, had kept my upper half dry. I had to rest for about half an hour before I felt capable of driving back to Qacha's Nek: my legs were distinctly wobbly and my arms ached incredibly-I think from the force of fear with which I had been gripping the reins.

I was asked to give a lift to a trooper returning to Qacha's Nek, and as I prepared myself for the drive I told him about the hard day I had just experienced, but he did not sound impressed. He told me that the Basuto ponies were bred to cope with these conditions and gave me to understand that I should have expected nothing less than a safe return-but I was not convinced, and before we left I went outside into the rain and gave my unnamed horse a loving embrace, which seemed to surprise him.

I am not a good horseman, but I bless and thank the big, black horse on whose back I have spent nine hours this day. $\mathrm{He}$ never tried to cheat or to frighten me, a stranger and relative novice. While I was startled by the flashes of lightning and the thunder he remained calm and knowing and eventually gave me some of his strength and confidence. I suppose he does this work quite often and therefore knows about the whims of the elements in these parts, but he was nevertheless as sure of foot as a goat and as strong as an ox but more intelligent than both.

And what of the hardy, mountain people who experience these things as a natural, God given part of their lives ? I can only say that this trip has given me a deep and lasting respect for them and their way of life. Patients often arrive at the hospital on horseback. There are no ambulances to help them on their way and not infrequently they fail to arrive before it is too late to help them.

I finally arrived home in Qacha's Nek at $1030 \mathrm{pm}$. Marta had just finished doing an emergency operation and was too tired to listen to my adventures, so we both went to sleep at once but my head was filled with vivid images of beautiful black horses climbing black mountains in the kingdom in the sky.

I suppose you could say that it was just another day's work, but here, every day is an adventure in one way or another and the life we lead is as vivid as a rainbow in the sky: neither Marta nor I are in a rush to change this way of life, for somehow we can both appreciate living a little closer to the earth than we did before. 